\title{
About the use of semi-continuity in simply supported composite steel and concrete beams, to remove fireproof coatings for standard-fire resistance requirement of less than $\mathbf{3 0}$ minutes
}

\section{Sobre a consideração da semicontinuidade de vigas mistas de aço e concreto biapoiadas, para eliminar o revestimento contra fogo para TRRF inferiores a 30 minutos}
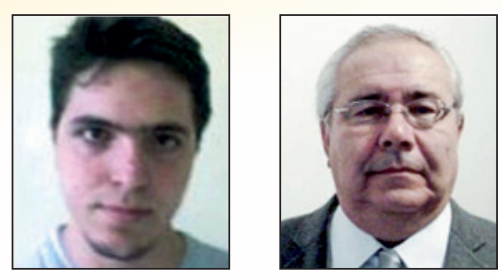

\author{
L. C. ROMAGNOLI \\ lucas.romagnoli@usp.br \\ https://orcid.org/0000-0002-3693-1128 \\ V. P. SILVA a \\ valpigss@usp.br \\ https://orcid.org/0000-0003-3302-8520
}

\section{Abstract}

Previous studies of the behavior under fire conditions of composite steel and concrete beams, not subjected to local buckling (compact steel profile), showed that it's not possible to justify, by design code methods, the absence of fire coating for 30 minutes standard-fire resistance requirement, even when considering the support rotational stiffness provided by the upper longitudinal slab reinforcement (semi-continuity). The purpose of this work is to verify the viability of this proposal for lower standard-fire resistance time, which, although rare, may occur with the use of the equivalent time method.

Keywords: fire, composite steel concrete beam, semi-continuous.

\section{Resumo}

Estudos anteriores do comportamento sob ação do incêndio de vigas mistas de aço e concreto, sem instabilidades locais (ditas compactas), considerando a rigidez à flexão nos apoios fornecida pela armadura negativa longitudinal à viga (semicontinuidade), mostraram que não é possível justificar a ausência de revestimento contra fogo para tempos requeridos de resistência ao fogo (TRRF) de 30 minutos utilizando métodos normatizados. O objetivo deste trabalho é verificar a viabilidade dessa proposta para tempos inferiores, que, embora raros, podem ocorrer com o uso do método do tempo equivalente.

Palavras-chave: incêndio, viga mista de aço e concreto, semicontínua.

Escola Politécnica da Universidade de São Paulo, São Paulo, SP, Brasil. 


\section{Introduction}

\subsection{Objective}

A simply supported composite steel and concrete beam designed at room temperature, when analyzed in a fire situation according to design procedures, generally does not have sufficient structural safety, unless fireproof coatings are present. Such solution is responsible for raising costs related to the composite structural system.

The objective of this study is to evaluate the behavior of composite steel and concrete beams in fire situation, taking into consideration the rotational stiffness of the supports provided by the slab's reinforcement mesh and by the restriction of the steel profile's lower flange, creating a composite connection and ensuring a semi-continuous behavior, as shown in Figure 1.

The ultimate limit state was analyzed using a simplified method according to ABNT NBR 14323 [1] standard, taking into account the cross section's plastic properties. Since this standard does not explicitly presents the necessary design formulation, those are developed in detail by Romagnoli and Silva [2].

For a better understanding of the presented results, the load factor is defined here as the ratio between the resistant bending moments in fire situation (considering the semi-continuity of the composite beam) and the resistant bending moment at room temperature (considering a simply supported composite beam), according to Equation (1).

load factor $=\frac{M_{R d, f i}^{+}+M_{R d, f i}^{-}}{M_{R d, 0}^{+}}$

Previous results (Romagnoli and Silva [2]) showed that it is not possible, for unprotected semi-continuous composite beams, to justify load factors higher than 0.7 for a 30 minute standard-fire resistance requirement following standard procedures (such criteria was adopted since ABNT NBR 14323 [1] allows, for simplicity, the use of a 0.70 load factor, described in terms of internal forces, for the fire ultimate limit state design). It is necessary to evaluate the same procedures for standard-fire resistance requirements of less than 30 minutes which, although not so common, can be adopted according to the so-called time equivalence method.

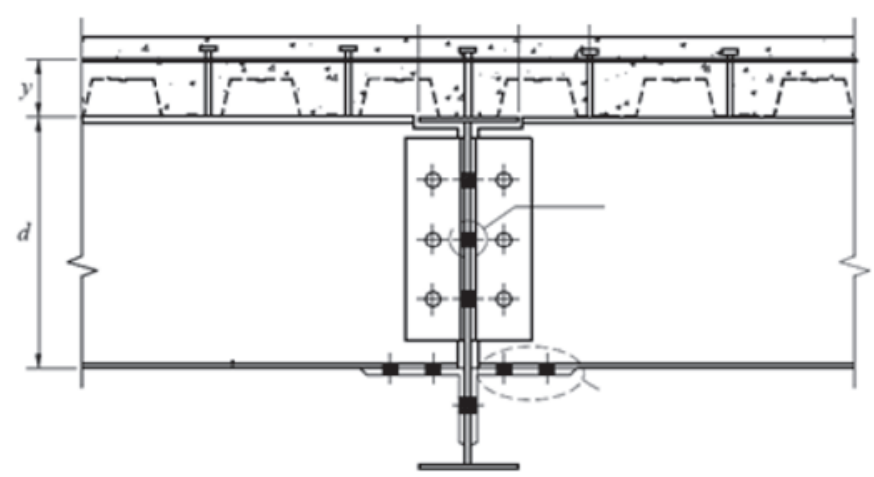

Figure 1

Composite connection

(adapted from ABNT NBR 8800 [11])

\subsection{Background}

Usually steel structures are associated with the imperative need to adopt fireproof coatings. Fire engineering studies aim to break this paradigm by better understanding the phenomena associated with the fire itself or the behavior of structures at elevated temperatures, thus allowing safer and more economical buildings.

Robinson and Latham (1986, apud Wang [3]) point out that in 1986 the use of fireproof coatings represented $30 \%$ of the total cost of a steel structure, which generated a major disadvantage in relation to concrete structures. With this problem in mind, both the steel industry and the scientific community sought to study the behavior of structures under fire.

The benefits of composite steel and concrete construction regarding the building fire resistance, when compared to the isolated steel structural member analyzed in laboratory, have been the object of studies by several authors. Comparing a steel and concrete composite beam numerical model to the registered results of the Cardington tests, Usmani et al. [4] emphasize the importance of taking the materials thermal expansion coefficient into consideration so that the models are close to reality and also conclude that the concrete slab large deformations induce a catenary behavior in the beam, responsible for preventing its collapse, highlighting the importance of the reinforcement mesh present in the slab to resist these nonlinear effects, expressively increasing the capacity of the composite beams.

Kodur et al. [5] noticed the importance of taking the catenary effect on the concrete slab into consideration when evaluation the fire resistance of a floor by comparing the results of a numerical model with a single floor system laboratory tests. The internal beams were unprotected, while the outer edge beams (which support the internal beams) received fireproof coatings rated for a standardfire resistance requirement of 60 minutes. Both in the numerical analysis and in the laboratory tests, the system withstand higher times, ranging from 85 to 110 minutes. The concrete slab was able to transfer the loads acting on the weakened internal beams to the external ones.

Huang et al. [6] emphasize the role of the reinforcement mesh present in the concrete slab to resist catenary stresses. By using finite elements they analyzed the impact of three different reinforcement meshes, noting that the reinforcement ratio becomes relevant after the unprotected beams that support the floor reach a temperature of $500^{\circ} \mathrm{C}$, moment when the nonlinearity is mobilized by the great deformations. The author concludes that the concrete slab capacity in fire situation is directly dependent on the configuration and strength of the slab's reinforcement mesh.

The consideration of the semi-continuity in the fire analysis of a composite beam has already been proposed by loannides and Mehta [7] who analyzed the cross section plastic capacity in the middle of the span and in the supports and affirmed, for the protected case, that there is a relevant structural strength increase. The authors state that most composite beams are designed at room temperature to meet service limits states and that there is a reserve in their structural capacity as the deformation limit is not considered in fire design.

Fakury et al. [8] compared the case of a simply supported and semi-continuous composite beam with fireproof coating, using the 
design method proposed by Eurocode EN 1994-1-2 [9]. As a conclusion, they found a strength capacity increase of $116 \%$ to $123 \%$ of the protected beam when analyzed as semi-continuous in comparison to the simply supported case.

Fischer and Varma [10] analyzed three-dimensional finite-element models of composite beams with typical hinged connections (shear plates, single-angles and double-angles). They compared a single frame model with models considering the continuity of the slab through the floor, thus having a resistant negative bending moment in the support regions. As a conclusion, they affirm that the continuity of the slab in the supports and the reinforcement mesh present in the slab have great influence on the behavior of the beam and the connections during fire, also concluding that there was no premature failure of the connections during fire exposure. Romagnoli and Silva [2] studied the behavior of unprotected composite beams under fire taking into consideration the negative moment resistance in the supports provided by the slab's reinforcement mesh and restriction of the steel profile's lower flange, forming a composite connection, and concluded that, although there is a significant increase in the strength of the semi-continuous composite beam compared to the simply supported case (about $90 \%$ ), this procedure is not enough to dispense fireproof coatings using the design method according to the ABNT NBR 14323 [1] standard, for 30 minutes standard-fire resistance requirement. This paper represents the continuation of these studies for lower standard-fire resistance times.

\subsection{Problem analysis}

The study was carried out for several cross sections, covering the variety of Gerdau brand profiles and 8 to $18 \mathrm{~cm}$ flat slab thicknesses. Following the recommendation of ABNT NBR 8800 [11] item 0.2.4.1.1, adjusted for fire situation as suggested by ABNT NBR 14323 [1] by reducing the slenderness parameters by 0.85 of its room temperature values, some profiles classified as a slender, that is, with a flange width and thickness ratio greater than $0,32 \sqrt{\mathrm{E} / \mathrm{f}_{\mathrm{y}}}$, were not considered in the analysis. The compressive strength of the concrete was assumed $30 \mathrm{MPa}$ and the steel yield strength $345 \mathrm{MPa}$. The shading factor was calculated as recommended by [1].

The distortional buckling that may occur in the negative bending moment regions of composite beams was not considered. Therefore, for direct use of the presented results, it must be ensured that the $\lambda_{\text {dist }}$ parameter, determined according to ABNT NBR 8800 [13] O.2.5.2, is higher than 0.4. ABNT NBR 14323 [1] does not provide specific recommendations for distortional buckling of composite beams in fire situation, but in case of cold formed profiles it is advised $\lambda_{\text {dist }}$ to be calculated as at room temperature, however with the use of a steel yield strength reduction factor recommended for local buckling cases, $\mathrm{k}_{\sigma, \theta}$.

The effective width of the concrete slab was 2 meters for all cases. The slab reinforcement ratio was such that it allowed the development of the maximum negative bending moment resistance. The number of shear connectors was the required for full iteration at room temperature.

The moment resistant capacity of the semi-continuous composite beams was evaluated by varying the standard-fire resistance requirement by one minute, successively. One of the IT08 [12] rec- ommendations when using the equivalent time method is to adopt a 15 minute lower limit, so the analyzes comprise the 15 to 30 minutes time range.

The objective is to determine the load factors for each profile and slab thickness. By varying the standard-fire resistance requirement it is possible to define in which time the load factor becomes higher than 0.7 when adopting the maximum possible reinforcement ratio. Again, such a criterion was used since ABNT NBR 14323 [1] allows, for simplicity, the adoption of a load factor of 0.70 , described in terms of internal forces, for the fire ultimate limit state design. Numerical studies, still to be published, shows that the temperature distribution along the height of the steel profile becomes almost uniform with the evolution of the standard fire, so that the effects associated with the thermal gradient are reduced with time. All the fire resistance times found in the numerical models for the semi-continuous condition were superior to those estimated by design methods and also superior to the simply supported case, even considering the indirect stresses caused by thermal expansion. With that in mind, the hypothesis of neglecting stresses caused by the thermal gradient is valid for standard-fire times greater than 15 minutes, since the consideration of the geometric and material nonlinearity was enough to mitigate the harmful effects of the thermal expansion and rotational restraint of the supports. It is worth noting that in order to take advantage of such beneficial effects, the reinforcement mesh ratio should be extended to the entire length of the beam, not only in the region of negative bending moments, since the slab must withstand catenary stresses along the span that arise from the large displacements observed during fire.

\section{Concrete slab temperature}

Since ABNT NBR 14323 [1] does not indicate the slab's slices temperatures for less than 30 minutes standard-fire resistance requirement it was necessary to evaluate those temperatures with aid of a numerical model. To perform the thermal analysis, a numerical model was developed in ABAQUS simulating the temperature field

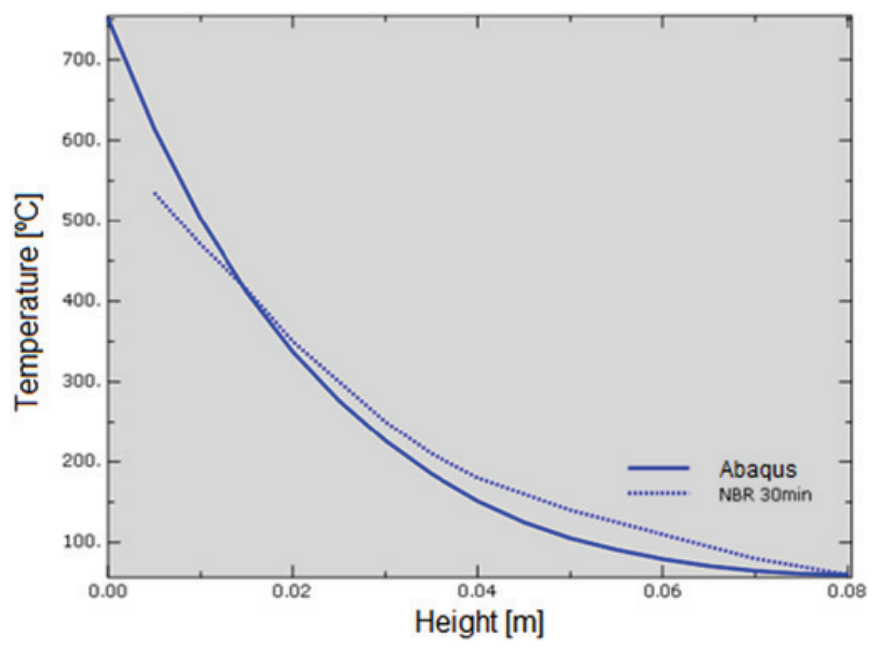

Figure 2

Temperature as function of the slab height, 30 minutes 


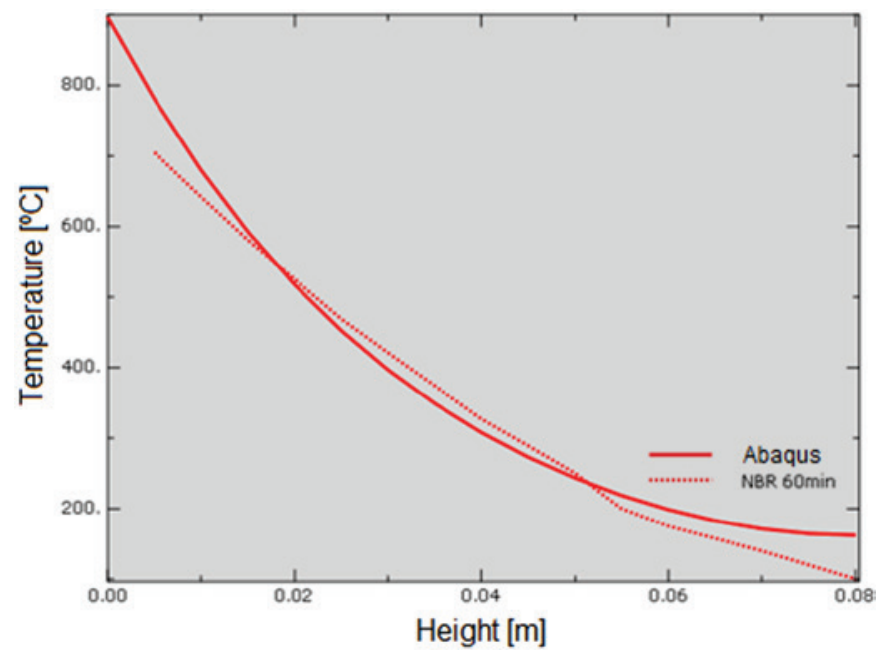

Figure 3

Temperature as function of the slab height, 60 minutes

of a slab with $8 \mathrm{~cm}$ thickness under the standard fire. The concrete thermal properties followed the recommendations of ABNT NBR 15200 [13]. The emissivity was considered constant and equal to 0.7 and the Stefan-Boltzmann constant equal to $5,669 \times 10^{-8} \mathrm{~W} /\left(\mathrm{m}^{2}{ }^{\circ} \mathrm{C}\right)$. The finite elements mesh was constructed by 8 nodes three-dimensional prismatic elements, so called DC3D8.

To evaluate the behavior of the numerical model, the results were initially compared to the values recommended by ABNT NBR 14323 [1] for greater standard-fire resistance requirement times. The graphs shown in Figure 2 and Figure 3 represent the temperature distribution along the height of the concrete slab for standard-fire resistance requirement of 30 and 60 minutes respectively, where 0 is the slab underside. The dotted line indicates the values recommended by the design standard and the full line the temperatures determined by the numerical model. It is noted that the

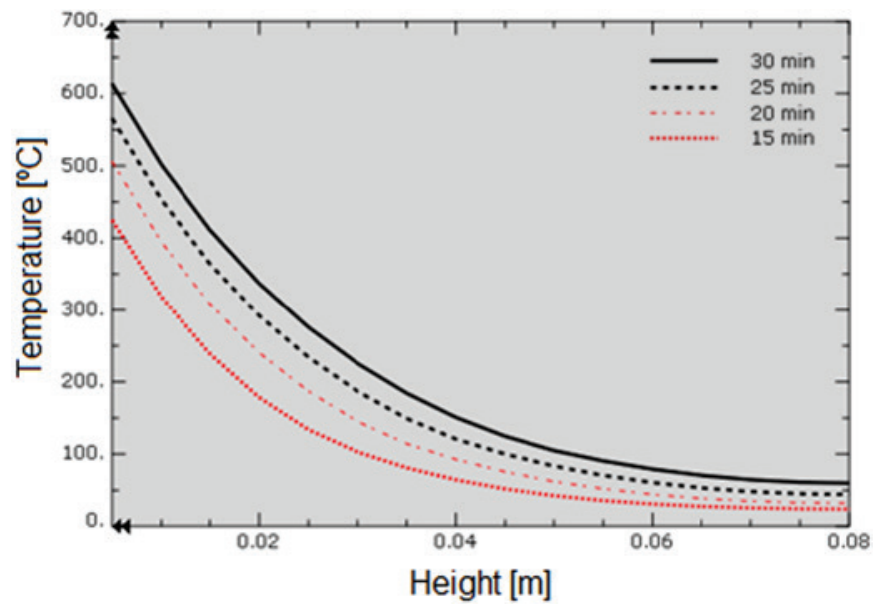

Figure 4

Temperature as function of the slab height, times less than 30 minutes

results are coherent and present good relation when compared to the design recommendations.

With the objective of evaluating temperatures below 30 minutes in mind, the graph of Figure 4 indicates the results for 15, 20 and 25 minutes. Lower times were not recorded since 15 minutes is the lower limit recommended by IT08 [12] when using the equivalent time method.

Table 1 presents the temperature values of each slab slice calculated by the thermal analysis in a similar manner as the ABNT NBR 14323 [1] standard. Those values were adopted when determining the design positive bending moment resistance of the composite section. For intermediate standard-fire times, linear interpolation was performed.

\section{Results}

Table 2 to Table 5 indicate the load factors, Equation (1), for

Table 1

Concrete slab temperature distribution $\left[{ }^{\circ} \mathrm{C}\right]$ for standard fire resistance requirement of less than 30 minutes

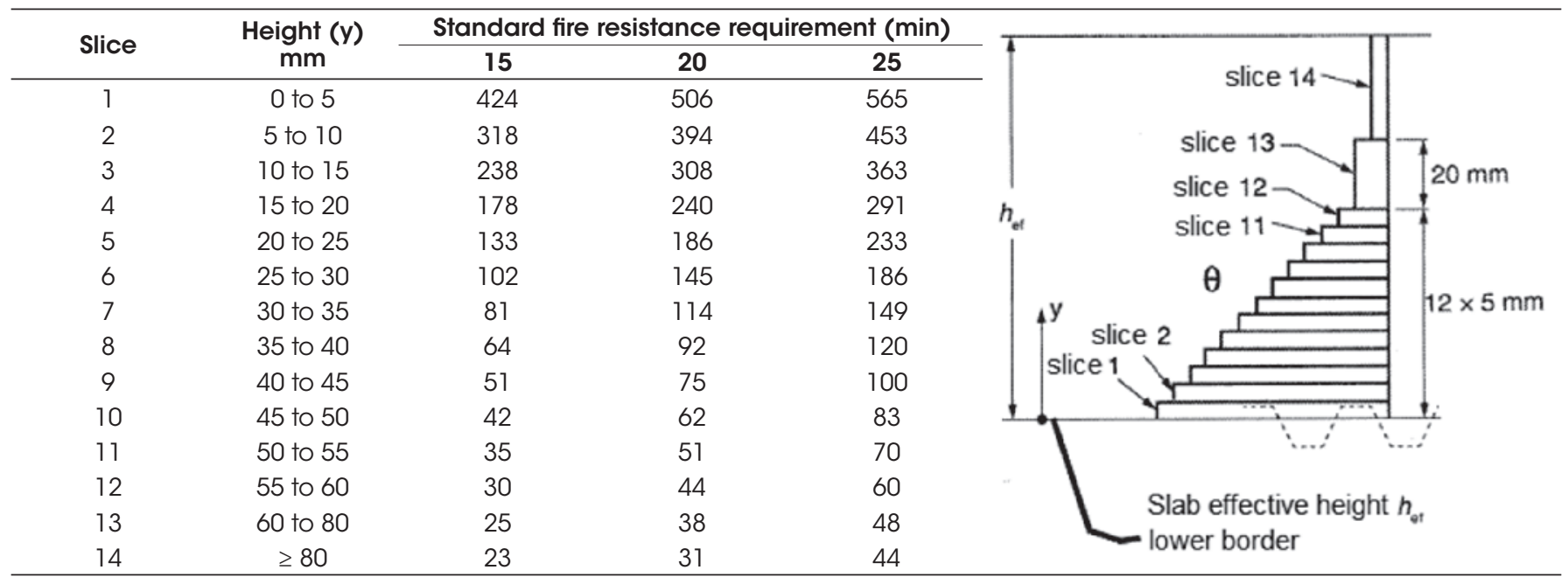


standard-fire resistance requirements ranging from 15 up to 30 minutes, for slabs with $10 \mathrm{~cm}$ thickness and steel profiles of the Gerdau brand. The column indicated as "SS" shows the load factor for the simply supported condition, which means, without taking the negative bending moment resistance into consideration. The column indicated as "SC" shows the load factor for the semi-continuous condition with adoption of the maximum reinforcement ratio, which is indicated in Table 6 and Table 7. The highlighted values represent loading factors greater than 0.7 , therefore, if there is a highlight value in the column indicated as "SS" it is concluded that the unprotected beam has enough structural capacity in fire even without considering the semi-continuity (no reinforcement mesh present) for the associated standard-fire resistance requirement. With these values we can know, for a given load factor and steel profile, if the consideration of the semi-continuity, adopting the maximum reinforcement rate, is sufficient to justify the design standard-fire resistance requirement time. The tables should be used according to the following calculation steps:

1. Determine the fire design load factor, remembering that 0.7 is a simplified recommendation of ABNT NBR 14323 [1]; a more precise determination of the building dead and live loads can lead to lower load factors. E.g.: a building fire design has a 0.6 load factor;

2. Identify the structural design geometric characteristics. E.g.: the composite beam to be analyzed is made of a W460x74,0 profile and a $10 \mathrm{~cm}$ thickness slab;

3. Use Table 2 to Table 5 to determine the standard-fire resistance requirement where the load factor is greater than the

\section{Table 2}

Load factors as function of the standard fire resistance requirement for composite beams with $10 \mathrm{~cm}$ slab and Gerdau profile series W150-W360

\begin{tabular}{|c|c|c|c|c|c|c|c|c|c|c|c|c|c|c|c|c|}
\hline \multicolumn{17}{|c|}{ Standard fire resistance requirement ( 30 to 23 minutes), series $W 150-W 360$, tc $=10 \mathrm{~cm}$} \\
\hline \multirow{2}{*}{ Name } & \multicolumn{2}{|c|}{30} & \multicolumn{2}{|c|}{29} & \multicolumn{2}{|c|}{28} & \multicolumn{2}{|c|}{27} & \multicolumn{2}{|c|}{26} & \multicolumn{2}{|c|}{25} & \multicolumn{2}{|c|}{24} & \multicolumn{2}{|c|}{23} \\
\hline & SS & SC & SS & SC & SS & SC & SS & SC & SS & SC & SS & SC & SS & SC & SS & SC \\
\hline W $150 \times 18.0$ & 0.11 & 0.20 & 0.11 & 0.21 & 0.12 & 0.21 & 0.12 & 0.22 & 0.13 & 0.23 & 0.13 & 0.24 & 0.14 & 0.26 & 0.15 & 0.28 \\
\hline W 150x24.0 & 0.12 & 0.22 & 0.12 & 0.23 & 0.13 & 0.24 & 0.14 & 0.25 & 0.15 & 0.26 & 0.16 & 0.28 & .17 & 0.31 & 0.19 & 0.35 \\
\hline W 150x37.1 & 0.14 & 0.26 & 0.15 & 0.28 & 0.16 & 0.29 & 0.17 & 0.32 & 0.19 & 0.35 & 0.22 & 0.40 & .24 & 0.44 & .27 & 0.49 \\
\hline W 200x22.5 & 0.11 & 0.20 & 0.11 & 0.21 & 0.12 & 0.22 & 0.12 & 0.23 & 0.13 & 0.24 & 0.13 & 0.25 & 0.14 & 0.26 & 0.15 & 0.28 \\
\hline W 200x31.3 & 0.12 & 0.22 & 0.13 & 0.23 & 0.13 & 0.24 & 0.14 & 0.26 & 0.15 & 0.27 & 0.16 & 0.29 & 0.17 & 0.32 & 0.19 & 0.35 \\
\hline W 200x41.7 & 0.14 & 0.25 & 0.15 & 0.27 & 0.15 & 0.28 & 0.16 & 0.30 & 0.18 & 0.34 & 0.20 & 0.38 & 0.23 & 0.42 & 0.25 & 0.47 \\
\hline W 200x59.0 & 0.18 & 0.33 & 0.19 & 0.36 & 0.22 & 0.40 & 0.24 & 0.44 & 0.26 & 0.49 & 0.30 & 0.55 & 0.33 & 0.61 & 0.36 & 0.67 \\
\hline W 200x71.0 & 0.24 & 0.44 & 0.26 & 0.48 & 0.29 & 0.53 & 0.32 & 0.59 & 0.35 & 0.65 & 0.39 & 0.72 & 0.43 & 0.80 & 0.48 & 0.90 \\
\hline W 200x86.0 & 0.31 & 0.57 & 0.34 & 0.63 & 0.37 & 0.69 & 0.40 & 0.76 & 0.44 & 0.84 & 0.49 & 0.94 & 0.55 & 1.04 & 0.60 & 1.16 \\
\hline W 250x22.3 & 0.11 & 0.20 & 0.11 & 0.21 & 0.11 & 0.21 & 0.12 & 0.22 & 0.12 & 0.23 & 0.13 & 0.24 & 0.13 & 0.25 & 0.14 & 0.27 \\
\hline W $250 \times 25.3$ & 0.11 & 0.21 & 0.11 & 0.21 & 0.12 & 0.22 & 0.12 & 0.23 & 0.13 & 0.24 & 0.13 & 0.25 & 1.14 & 0.26 & 0.15 & 0.28 \\
\hline W 250x28.4 & 0.11 & 0.21 & 0.12 & 0.22 & 0.12 & 0.23 & 0.13 & 0.24 & 0.13 & 0.25 & 0.14 & 0.26 & 0.15 & 0.28 & 0.16 & 0.30 \\
\hline W 250x38.5 & 0.12 & 0.23 & 0.13 & 0.24 & 0.13 & 0.25 & 0. & 0.26 & 0.15 & 0.28 & 0.16 & 30 & .18 & .33 & 0.20 & 0.37 \\
\hline W 250x44.8 & 0.13 & 0.25 & 0.14 & 0.26 & 0.15 & 0.27 & 0.15 & 0.29 & 0.17 & 0.31 & 0.19 & 0.35 & 0.21 & 0.39 & 0.23 & 0.43 \\
\hline W 250x89.0 & 0.24 & 0.45 & 0.27 & 0.50 & 0.30 & 0.55 & 0.32 & 0.61 & 0.36 & 0.67 & 0.39 & 0.74 & 0.43 & 0.82 & 0.48 & 0.93 \\
\hline W 250x101.0 & 0.30 & 0.56 & 0.32 & 0.61 & 0.35 & 0.67 & 0.39 & 0.73 & 0.42 & 0.80 & 0.47 & 0.90 & 0.52 & 1.01 & 0.58 & 1.12 \\
\hline W 250x115.0 & 0.35 & 0.67 & 0.38 & 0.73 & 0.41 & 0.79 & 0.45 & 0.88 & 0.50 & 0.98 & 0.56 & 1.09 & 0.61 & 1.20 & 0.66 & 1.31 \\
\hline W 310x23.8 & 0.11 & 0.20 & 0.11 & 0.21 & 0.11 & 0.21 & 0.12 & 0.22 & 0.12 & 0.22 & 0.13 & 0.23 & .13 & 0.24 & 0.14 & 0.26 \\
\hline W $310 \times 28.3$ & 0.11 & 0.21 & 0.11 & 0.21 & 0.12 & 0.22 & 0.12 & 0.23 & 0.13 & 0.24 & 0.13 & 0.25 & 0.14 & 0.26 & 0.15 & 0.28 \\
\hline W $310 \times 32.7$ & & & 0.12 & 0.22 & & 0.23 & & & & & & & & & & \\
\hline W $310 \times 44.5$ & 0.12 & 0.23 & 0.13 & 0.24 & 0.13 & 0.25 & 0.14 & 0.26 & 0.15 & 0.28 & 0.16 & 0.30 & 0.18 & 0.33 & 0.20 & 0.37 \\
\hline W $310 \times 52.0$ & 0.13 & 0.25 & 0.14 & 0.26 & 0.14 & 0.27 & 0.15 & 0.29 & 0.17 & 0.32 & 0.19 & $0.3^{3}$ & 0.21 & 0.3 & 0.23 & 0.43 \\
\hline W $360 \times 32.9$ & 0.11 & 0.21 & 0.11 & 0.21 & 0.12 & 0.22 & 0.12 & 0.23 & 0.13 & 0.24 & 0.13 & 0.25 & 0.14 & 0.26 & 0.15 & 0.28 \\
\hline W $360 \times 39.0$ & 0.11 & 0.22 & 0.12 & 0.22 & 0.12 & 0.23 & 0.13 & 0.24 & 0.13 & 0.25 & 0.14 & 0.27 & 0.15 & 0.29 & 0.16 & 0.31 \\
\hline W $360 \times 51.0$ & 0.12 & 0.23 & & 0.24 & 0.13 & 0.25 & & & 0.15 & 0.28 & & & 0.18 & 0.33 & 0.19 & \\
\hline W $360 \times 57.8$ & 0.13 & 0.24 & 0.13 & 0.25 & 0.14 & 0.27 & 0.15 & 0.28 & 0.16 & 0.30 & 0.18 & 0.33 & 0.20 & 0.37 & 0.22 & 0.41 \\
\hline W $360 \times 64.0$ & 0.14 & 0.26 & 0.14 & 0.27 & 0.15 & 0.29 & 0.17 & 0.31 & 0.18 & 0.34 & 0.20 & 0.38 & 0.22 & 0.42 & 0.25 & 0.47 \\
\hline W $360 \times 72.0$ & 0.15 & 0.28 & 0.16 & 0.30 & 0.17 & 0.32 & 0.19 & 0.36 & 0.21 & 0.39 & 0.23 & 0.43 & 0.25 & 0.48 & 0.28 & 0.53 \\
\hline W 360x79.0 & 0.16 & 0.31 & 0.18 & 0.33 & 0.20 & 0.37 & 0.21 & 0.40 & 0.24 & 0.44 & 0.26 & 0.49 & 0.29 & 0.55 & 0.32 & 0.60 \\
\hline W 360x91.0 & 0.18 & 0.34 & 0.20 & 0.37 & 0.22 & 0.41 & 0.24 & 0.45 & 0.26 & 0.50 & 0.29 & 0.55 & 0.32 & 0.61 & 0.35 & 0.67 \\
\hline W 360x101.0 & 0.21 & 0.39 & 0.23 & 0.43 & 0.25 & 0.48 & 0.28 & 0.53 & 0.31 & 0.58 & 0.33 & 0.64 & 0.37 & 0.70 & 0.42 & 0.80 \\
\hline W $360 \times 110.0$ & 0.24 & 0.45 & 0.26 & 0.49 & 0.28 & 0.54 & 0.31 & 0.59 & 0.34 & 0.65 & 0.37 & 0.71 & 0.42 & 0.81 & 0.47 & 0.91 \\
\hline W $360 \times 122.0$ & 0.27 & 0.51 & 0.29 & 0.56 & 0.32 & 0.61 & 0.35 & 0.67 & 0.38 & 0.73 & 0.43 & 0.83 & 0.48 & 0.93 & 0.53 & 1.04 \\
\hline
\end{tabular}

*SS = Simply Supported; SC = Semi-continuous; Highlighted values shows load factors greater than 0.7 . 
fire design one for the simply supported case (column "SS"). E.g.: Table 5 shows that the $W 460 \times 74,0$ profile has a 0.62 load factor for the simply supported case and 15 minutes standardfire resistant requirement. For higher times all load factors are lower than the fire design one (0.6);

4. Use Table 2 to Table 5 to determine the standard-fire resistance requirement where the load factor is greater than the fire design one for the semi-continuous case (column "SC"). E.g.: Table 5 shows that the $\mathrm{W} 460 \times 74,0$ profile has a 0.67 load factor for the semi-continuous case and 19 minutes standardfire resistant requirement. For higher times all load factors are lower than the fire design one (0.6);

5. Use Table 6 or Table 7 to determine the reinforcement ratio associated with the semi-continuous case for the development of the maximum negative bending moment resistance. E.g.: Table 7 shows that the W460x 74,0 profile has a $1,28 \%$ reinforcement ratio for the 19 minutes standard-fire resistant requirement, found on step 4;

6. As a conclusion it is possible to dispense fireproof coating, based on design standard procedures, for standard-fire resistant requirement varying between the simply supported case, without any additional mesh reinforcement, and the semicontinuous case, with adoption of the maximum reinforcement ratio. E.g.: it is possible to dispense fireproof coatings for standard-fire resistance requirement of 15 minutes up to 19 minutes, for reinforcement ratios varying from $0 \%$ to $1,28 \%$;

7. In case the design standard-fire resistant requirement is an intermediate value to those found in the steps above, it is

\section{Table 3}

Load factors as function of the standard fire resistance requirement for composite beams with $10 \mathrm{~cm}$ slab and Gerdau profile series W150-W360 (continuation)

\begin{tabular}{|c|c|c|c|c|c|c|c|c|c|c|c|c|c|c|c|c|}
\hline \multicolumn{17}{|c|}{ Standard fire resistance requirement (22 to 15 minutes), series $W 150-W 360$, tc $=10 \mathrm{~cm}$} \\
\hline \multirow{2}{*}{ Name } & \multicolumn{2}{|c|}{22} & \multicolumn{2}{|c|}{21} & \multicolumn{2}{|c|}{20} & \multicolumn{2}{|c|}{19} & \multicolumn{2}{|c|}{18} & \multicolumn{2}{|c|}{17} & \multicolumn{2}{|c|}{16} & \multicolumn{2}{|c|}{15} \\
\hline & SS & SC & SS & SC & SS & SC & SS & SC & SS & SC & SS & SC & SS & SC & SS & SC \\
\hline W 150x18.0 & 0.17 & 0.31 & 0.18 & 0.33 & 0.20 & 0.36 & 0.22 & 0.40 & 0.25 & 0.45 & 0.28 & 0.50 & 0.31 & 0.56 & 0.36 & 0.63 \\
\hline W 150x24.0 & 0.21 & 0.39 & 0.24 & 0.43 & 0.27 & 0.48 & 0.30 & 0.54 & 0.34 & 0.62 & 0.39 & 0.70 & 0.45 & 0.80 & 0.52 & 0.91 \\
\hline W 150x37.1 & 0.31 & 0.56 & 0.34 & 0.62 & 0.38 & 0.70 & 0.44 & 0.79 & & 0.91 & 0.56 & 1.03 & 0.64 & 1.16 & 0.72 & 1.31 \\
\hline W $200 \times 22.5$ & 0.17 & 0.31 & 0.18 & 0.33 & 0.20 & 0.37 & 0.22 & 0.41 & 0.25 & 0.45 & 0.27 & 0.50 & 0.31 & 0.55 & 0.35 & 0.62 \\
\hline W 200x31.3 & 0.21 & 0.39 & 0.24 & 0.44 & 0.27 & 0.49 & 0.30 & & 0.34 & 0.62 & & 0.72 & 0.45 & 0.83 & 0.51 & 0.95 \\
\hline W 200x41.7 & 0.28 & 0.52 & 0.32 & 0.59 & 0.36 & 0.65 & 0.40 & 0.75 & 0.46 & 0.86 & 0.52 & 0.98 & 0.59 & 1.11 & 0.67 & 1.27 \\
\hline W 200x59.0 & 0.40 & 0.75 & 0.45 & 0.85 & 0.51 & 0.96 & 0.57 & 1.08 & 0.64 & 1.22 & 0.72 & & 0.80 & 1.53 & 0.89 & 68 \\
\hline W 200x71.0 & 0.53 & 1.01 & 0.59 & 1.12 & 0.65 & 1.24 & 0.72 & 1.38 & & 1.54 & 0.88 & & & 1.83 & 1.02 & 1.94 \\
\hline W 200x86.0 & 0.66 & 1.27 & 0.72 & 1.41 & 0.80 & 1.56 & 0.87 & 1.71 & 0.95 & 1.85 & 1.02 & 1.97 & 1.09 & 2.05 & 1.14 & 2.11 \\
\hline W $250 \times 22.3$ & 0.16 & 0.29 & 0.17 & 0.31 & 0.18 & 0.33 & 0.19 & 0.36 & 0.22 & 0.39 & 0.24 & 0.42 & 0.26 & 0.46 & 0.29 & 0.51 \\
\hline W 250x25.3 & 0.16 & 0.31 & 0.18 & 0.33 & 0.19 & 0.36 & 0.21 & 0.40 & 0.24 & 0.44 & 0.26 & 0.48 & 0.29 & 0.53 & 0.34 & 0.60 \\
\hline W 250x28.4 & 0.18 & 0.3 & 0.19 & 0.36 & 0.21 & 0.40 & 0.2 & 0.44 & 0.26 & 0.49 & & & 34 & 0.62 & .39 & 0.71 \\
\hline W 250x38.5 & 0.22 & 0.41 & 0.25 & 0.46 & 0.27 & 0.5 & 0.31 & 0.57 & 0.35 & 0.65 & 0.40 & 0.75 & 0.46 & 0.86 & 0.52 & 0.99 \\
\hline W 25 & 0.26 & 0.48 & 0.29 & 0.53 & 0.32 & 0.59 & 0.36 & 0.67 & 0.42 & 0.78 & 0.47 & & 0.54 & 1.01 & 0.62 & 1.17 \\
\hline W 250 & 0.54 & 1.04 & 0.60 & 1.16 & 0.66 & 1.28 & 0.73 & 1.43 & 0.82 & 1.61 & 0.90 & 1.78 & 0.97 & 1.92 & 1.05 & 2.03 \\
\hline W 250x101.0 & 0.63 & 1.24 & 0.69 & 1.36 & 0.77 & 1.51 & 0.84 & 1.68 & 0.93 & 1.86 & 0.99 & 1.99 & 1.06 & 2.08 & 1.12 & 2.14 \\
\hline W 250x115.0 & 0.73 & 1.45 & 0.80 & 1.60 & 0.88 & 1.76 & 0.94 & 1.91 & 1.00 & 2.04 & 1.05 & 2.11 & 1.11 & 2.17 & 1.13 & 2.19 \\
\hline W 310x23.8 & 0.15 & 0.28 & 0.16 & 0.30 & 0.18 & 0.3 & 0.19 & 0. & 0.2 & 0.3 & 0.23 & & & 0.43 & 0. & 0.47 \\
\hline W 310 & 0.16 & 0.30 & 0.18 & 0.3 & 0.19 & 0.36 & 0.21 & 0.39 & 0.23 & 0.4 & 0.26 & & 0.29 & 0.52 & 0.33 & 0.59 \\
\hline W $310 \times 32.7$ & 0.18 & 0.33 & 0.19 & 0.36 & 0.21 & 0.40 & 0.24 & 0.44 & 0.26 & 0.49 & 0.29 & 0.55 & 0.34 & 0.62 & 0.39 & 0.71 \\
\hline W $310 \times 44.5$ & 0.22 & 0.41 & 0.24 & 0.45 & 0.27 & 0.50 & 0.30 & 0.56 & 0.34 & 0.63 & 0.39 & 0.73 & 0.45 & 0.84 & 0.51 & 0.96 \\
\hline W $310 \times 52.0$ & 0.25 & 0.48 & 0.28 & 0.53 & 0.31 & 0.59 & 0.36 & 0.67 & 0.41 & 0.78 & 0.47 & 0.89 & 0.53 & 1.01 & 0.61 & 1.17 \\
\hline W $360 \times 32.9$ & 0.16 & 0.31 & 0.18 & 0.3 & 0.19 & 0.3 & 0.21 & 0.40 & 0.23 & 0.44 & 0.26 & 0.48 & 0.28 & 0.54 & 0.33 & 0.60 \\
\hline W $360 \times 39.0$ & 0.18 & 0.34 & 0.20 & 0.38 & 0.22 & 0.41 & 0.24 & 0.46 & 0.27 & 0.51 & 0.31 & 0.57 & 0.35 & 0.66 & 0.40 & 0.76 \\
\hline W $360 \times 51.0$ & 0.21 & 0.40 & 0.24 & 0.45 & 0.26 & 0.50 & 0.29 & 0.55 & 0.33 & 0.63 & 0.38 & 0.73 & 0.44 & 0.83 & 0.50 & 0.96 \\
\hline W $360 \times 57.8$ & 0.24 & 0.45 & 0.27 & 0.50 & 0.30 & 0.56 & 0.33 & 0.63 & 0.39 & 0.73 & 0.44 & 0.84 & 0.50 & 0.96 & 0.58 & 1.12 \\
\hline W $360 \times 64.0$ & 0.28 & 0.52 & 0.31 & 0.58 & 0.34 & 0.64 & 0.39 & 0.74 & 0.45 & 0.86 & 0.51 & 0.97 & 0.58 & 1.11 & 0.66 & 1.28 \\
\hline W $360 \times 72.0$ & 0.31 & 0.59 & 0.35 & 0.66 & 0.40 & 0.76 & 0.45 & 0.86 & 0.51 & 0.98 & 0.58 & 1.11 & 0.66 & 1.28 & 0.75 & 1.46 \\
\hline W 360x79.0 & 0.36 & 0.68 & 0.40 & 0.77 & 0.46 & 0.88 & 0.51 & 0.99 & 0.58 & 1.12 & 0.66 & 1.28 & 0.74 & 1.45 & 0.83 & 1.63 \\
\hline W 360x91.0 & 0.40 & 0.76 & 0.45 & 0.87 & 0.51 & 0.98 & 0.57 & 1.10 & 0.64 & 1.25 & 0.72 & 1.42 & 0.81 & 1.61 & 0.90 & 1.77 \\
\hline W 360x101.0 & 0.47 & 0.91 & 0.52 & 1.02 & 0.58 & 1.14 & 0.65 & 1.27 & 0.73 & 1.45 & 0.82 & 1.63 & 0.90 & 1.79 & 0.97 & 1.94 \\
\hline W 360x1 10.0 & 0.52 & 1.02 & 0.58 & 1.14 & 0.64 & 1.27 & 0.72 & 1.43 & 0.81 & 1.61 & 0.89 & 1.78 & 0.95 & 1.92 & 1.02 & 2.00 \\
\hline W $360 \times 122.0$ & 0.58 & 1.15 & 0.65 & 1.28 & 0.72 & 1.44 & 0.80 & 1.61 & 0.88 & 1.78 & 0.94 & 1.91 & 1.00 & 2.00 & 1.07 & 2.07 \\
\hline
\end{tabular}

${ }^{*} \mathrm{SS}=$ Simply Supported; $\mathrm{SC}=$ Semi-continuous; Highlighted values shows load factors greater than 0.7 . 


\section{Table 4}

Load factors as function of the standard fire resistance requirement for composite beams with $10 \mathrm{~cm}$ slab and Gerdau profile series W410-W610

\begin{tabular}{|c|c|c|c|c|c|c|c|c|c|c|c|c|c|c|c|c|}
\hline \multicolumn{17}{|c|}{ Standard fire resistance requirement ( 30 to 23 minutes), series W410-W610, tc $=10 \mathrm{~cm}$} \\
\hline \multirow{2}{*}{ Name } & \multicolumn{2}{|c|}{30} & \multicolumn{2}{|c|}{29} & \multicolumn{2}{|c|}{28} & \multicolumn{2}{|c|}{27} & \multicolumn{2}{|c|}{26} & \multicolumn{2}{|c|}{25} & \multicolumn{2}{|c|}{24} & \multicolumn{2}{|c|}{23} \\
\hline & SS & SC & SS & SC & SS & SC & SS & SC & SS & SC & SS & SC & SS & SC & SS & SC \\
\hline W 410x46.1 & 0.12 & 0.22 & 0.12 & 0.23 & 0.12 & 0.24 & 0.13 & 0.25 & 0.14 & 0.26 & 0.14 & 0.27 & 0.15 & 0.29 & 0.17 & 0.32 \\
\hline W 410x60.0 & 0.13 & 0.24 & 0.13 & 0.25 & 0.14 & 0.26 & & 0.27 & & & & & & 0.35 & 0.20 & 0.39 \\
\hline W 410x67.0 & 0.13 & 0.25 & 0.14 & 0.26 & 0.14 & 0.27 & & 0.30 & & & & & & 0.39 & 0.23 & 0.43 \\
\hline W 410x75.0 & 0.14 & 0.27 & 0.15 & 0.28 & 0.16 & 0.30 & 0.17 & 0.33 & 0.19 & 0.36 & 0.21 & 0.39 & 0.23 & 0.44 & 0.26 & 0.48 \\
\hline W 410x & 0.15 & 0.29 & & & & & & & & & & & & & 0.29 & 0.56 \\
\hline & 0.12 & 0.22 & 0.1 & 0.23 & 0.12 & 0.24 & & 0.25 & & 0.26 & 0.14 & & & 0.29 & 0.17 & \\
\hline W 46 & 0.12 & 0.23 & 0.1 & 0.2 & 0.13 & 0.2 & & & & 0. & & & & 0.33 & 19 & 36 \\
\hline W 46 & 0.13 & 0.2 & 0.1 & 0.26 & 0.1 & 0.2 & & 0.2 & & & & & & 37 & & \\
\hline W 46 & 0.13 & 0.25 & 0.1 & 0.2 & 0.14 & 0.2 & 0. & 0.2 & & 0. & 0. & & & 0.39 & 0.22 & 43 \\
\hline W 46 & 0.14 & 0.2 & & & & & & & & & & & & .43 & 25 & \\
\hline & 0.15 & 0.2 & & 0.3 & 0.17 & & & & & & & & & 0.4 & 0. & \\
\hline W 46 & 0.16 & 0.30 & 0.1 & 0.3 & 0.19 & 0.3 & & & & 0.2 & & & & 0.52 & 0. & \\
\hline W 460 & 0.17 & 0.33 & 0.1 & 0.36 & 0.20 & 0.3 & 0.2 & 0.43 & & 0.2 & 0.2 & & & 0.58 & 0.34 & 0.65 \\
\hline W 530 & 0.12 & 0.23 & 0.1 & 0.2 & & 0.2 & & & & 0.2 & & & & 0. & 0. & \\
\hline W 53 & 0.12 & 0.2 & 0.1 & 0.24 & 0.1 & 0.2 & & & & 0.2 & 0.16 & & & 0.33 & 0.19 & .37 \\
\hline & 0.13 & 0.25 & & 0.2 & & 0.2 & & & & & & & & 0.39 & 0.22 & \\
\hline W 53 & 0.14 & 0.26 & & 0.27 & & & & & & & & & & & 0.24 & 0.45 \\
\hline W 530x101.0 & 0.14 & 0.28 & 0.15 & 0.29 & 0.17 & 0.32 & 0.18 & 0.35 & 0.20 & 0.38 & 0.22 & 0.42 & 0.24 & 0.46 & 0.26 & 0.51 \\
\hline & 0.15 & 0.29 & & 0.32 & & & & & & 0.41 & & & & 0.50 & 0.29 & \\
\hline W 610x101.0 & 0.13 & 0.25 & 0.14 & 0.27 & 0.14 & 0.28 & 0.15 & 0.30 & 0.17 & 0.32 & 0.18 & 0.35 & 0.20 & 0.39 & 0.22 & 0.43 \\
\hline W 610x113.0 & 0.14 & 0.27 & 0.15 & 0.29 & 0.16 & 0.31 & 0.18 & 0.34 & 0.1 & 0.37 & 0.21 & 0.41 & 0.23 & 0.45 & 0.26 & 0.50 \\
\hline W $610 \times 125.0$ & 0.16 & 0.30 & 0.17 & 0.32 & 0.18 & 0.35 & 0.20 & & & 0.42 & 0.24 & & 0.27 & 0.51 & 0.29 & 0.57 \\
\hline W 610x140.0 & 0.18 & 0.34 & 0.19 & 0.37 & 0.21 & 0.41 & 0.23 & 0.44 & 0.25 & 0.49 & 0.28 & 0.54 & 0.31 & 0.60 & 0.35 & 0.69 \\
\hline W 610x174.0 & 0.21 & 0.40 & 0.22 & 0.44 & 0.24 & 0.48 & 0.27 & 0.53 & 0.29 & 0.58 & 0.32 & 0.64 & 0.37 & 0.73 & 0.42 & 0.83 \\
\hline
\end{tabular}

*SS = Simply Supported; SC = Semi-continuous; Highlighted values shows load factors greater than 0.7 .

\section{Table 5}

Load factors as function of the standard fire resistance requirement for composite beams with $10 \mathrm{~cm}$ slab and Gerdau profile series W410-W610 (continuation)

\begin{tabular}{|c|c|c|c|c|c|c|c|c|c|c|c|c|c|c|c|c|}
\hline \multicolumn{17}{|c|}{ Standard fire resistance requirement (22 to 15 minutes), series $\mathrm{W} 410-W 610$, tc $=10 \mathrm{~cm}$} \\
\hline \multirow{2}{*}{ Name } & \multicolumn{2}{|c|}{22} & \multicolumn{2}{|c|}{21} & \multicolumn{2}{|c|}{20} & \multicolumn{2}{|c|}{19} & \multicolumn{2}{|c|}{18} & \multicolumn{2}{|c|}{17} & \multicolumn{2}{|c|}{16} & \multicolumn{2}{|c|}{15} \\
\hline & SS & SC & SS & SC & SS & SC & SS & SC & SS & SC & SS & SC & SS & SC & SS & SC \\
\hline W $410 \times 46.1$ & 0.19 & 35 & 0.20 & 0.39 & 0.22 & 0.43 & 0.25 & 0.47 & 0.28 & 0.53 & 0.31 & 0.60 & 0.36 & 0.69 & 0.41 & 0.79 \\
\hline W 410x60.0 & 22 & 1.43 & 0.25 & & 0.28 & & & & & 0.68 & & 0.78 & & 0.89 & .54 & \\
\hline W 410x67.0 & .25 & 0.48 & 0.28 & 0.53 & 0.31 & 9 & 0.36 & 0.68 & .41 & 0.79 & .47 & 0.90 & .54 & .04 & 0.62 & \\
\hline & .28 & & & & 36 & & & & & & & & & & & \\
\hline W 4 & 0.33 & 0.63 & 0.38 & 0.72 & 0.42 & 0.82 & 48 & 0.92 & & 06 & 0. & & 0.71 & 1.39 & 0.81 & \\
\hline & & & & & & & & & & & & & & & & \\
\hline & 0.21 & 0.40 & 0.2 & 0. & 0.26 & 0.4 & 0. & & & 0.62 & 0. & & .42 & 0.82 & 0.49 & \\
\hline & 0.24 & 0.4 & 0.2 & & 0.2 & & & & 0 & & & & & 7 & & \\
\hline & 0.2 & 0.4 & 0.2 & 0 & 0.3 & 0. & & 0. & & & & & & & 0.62 & \\
\hline & 0.28 & 0.5 & 0.3 & 0. & 0.3 & 0.6 & 0. & & & 0. & & & 0.6 & 1.17 & 0.69 & \\
\hline & 0 & & & 0. & & & & & & & & & & 33 & 0.77 & \\
\hline & & 0.6 & & & & & & & 57 & & 0. & & & 13 & 33 & \\
\hline W 46 & 0.3 & 0.75 & & 0.8 & 0.49 & 0.9 & & 1.08 & 0.64 & 1.26 & 0.72 & 1.41 & 1 & 1.55 & 0.90 & 1.68 \\
\hline & 0.19 & 0.3 & 0.21 & 0.3 & 0.23 & 0.42 & 0.25 & 0.46 & 0.28 & 0.51 & 0.31 & 0.58 & 37 & 0.66 & 0.43 & 0.77 \\
\hline & 0.21 & 0.40 & 0.23 & & 0.26 & 0.49 & 0.2 & & 0.33 & 0.6 & & & & 0.82 & & \\
\hline W 53 & 0.25 & 0.47 & 0.2 & 0.5 & 0.31 & 0.5 & 0.35 & 0.68 & 0.40 & 0.78 & 0.46 & 90 & 54 & 1.04 & 0.63 & 1.18 \\
\hline & & & & & & 0.6 & & & & & 0.2 & & 0. & 1.13 & 0.67 & 1.28 \\
\hline W 530 & 0.29 & 0.56 & 0.33 & 0.64 & 0.38 & 0.73 & 0.43 & & 0.49 & 0.96 & 0.57 & 1.12 & 0.66 & 1.28 & 0.75 & 1.43 \\
\hline W 530x109.0 & 0.32 & 0.63 & 0.37 & 0.72 & 0.42 & 0.82 & 0.47 & 0.92 & 0.54 & 1.07 & 0.63 & 1.24 & 0.72 & 1.39 & 0.81 & 1.53 \\
\hline & 0.25 & 0.48 & 0.27 & & & 0.59 & & 0.68 & & 0.78 & 0.47 & & & 1.06 & 0.64 & 1.21 \\
\hline W $610 \times 113.0$ & 0.28 & 0.55 & 0.32 & 0.62 & 0.37 & 0.71 & 0.41 & 0.81 & 0.48 & 0.94 & 0.56 & 1.10 & 0.64 & 1.26 & 0.74 & 1.40 \\
\hline & 0.33 & 0.65 & & & 0.43 & 0.84 & 0.48 & & 0.56 & 1.11 & 0.64 & 1.29 & 0.74 & 1.43 & 0.82 & 1.56 \\
\hline W 610x140.0 & 0.40 & 0.78 & 0.44 & 0.88 & 0.50 & 0.99 & 0.57 & 1.13 & 0.66 & 1.32 & 0.74 & 1.46 & & 1.58 & 0.89 & 1.69 \\
\hline W 610x174.0 & 0.46 & 0.93 & 0.51 & 1.04 & 0.58 & 1.19 & 0.66 & 1.36 & 0.75 & 1.55 & 0.82 & 1.68 & 0.90 & 1.81 & 0.98 & 1.89 \\
\hline
\end{tabular}


Table 6

Reinforcement ratio as function of the standard fire resistance requirement for development of the maximum negative bending moment, for composite beams with $10 \mathrm{~cm}$ slabs and Gerdau profiles series W150-W360

\begin{tabular}{|c|c|c|c|c|c|c|c|c|c|c|c|c|c|c|c|c|}
\hline \multicolumn{17}{|c|}{ Reinforcement ratio (\%) for standard fire resistance requirement (30 to 15 minutes), series W410-W610 - tc = $10 \mathrm{~cm}$} \\
\hline Name & 30 & 29 & 28 & 27 & 26 & 25 & 24 & 23 & 22 & 21 & 20 & 19 & 18 & 17 & 16 & 15 \\
\hline W 150x18.0 & 0.07 & 0.08 & 0.08 & 0.08 & 0.09 & 0.09 & 0.10 & 0.11 & 0.12 & 0.13 & 0.14 & 0.16 & 0.19 & 0.21 & 0.24 & 0.28 \\
\hline W 150x24.0 & 0.11 & 0.12 & & & 0.14 & & & 0.19 & 0.21 & 0.24 & 0.28 & & 0.36 & 0.42 & 0.48 & 0.54 \\
\hline W 150x37.1 & 0.21 & 0.22 & 0.24 & 0.27 & 0.30 & 0.35 & 0.39 & 0.44 & 0.50 & 0.57 & 0.64 & 0.73 & 0.82 & 0.91 & 1.02 & 1.11 \\
\hline W 200x22.5 & 0.09 & 0.10 & 0.10 & 0.10 & 0.11 & 0.12 & 0.12 & 0.14 & 0.15 & 0.16 & 0.18 & 0.20 & 0.23 & 0.26 & 0.30 & 0.35 \\
\hline W 200x31.3 & 0.14 & 0.15 & 0.16 & 0.17 & 0.19 & 0.20 & 0.22 & 0.26 & 0.29 & 0.33 & 0.37 & 0.43 & 0.49 & 0.56 & 0.64 & 0.71 \\
\hline W 200x41.7 & 0.23 & 0.24 & 0.26 & 0.29 & 0.33 & 0.37 & 0.42 & 0.47 & 0.54 & 0.61 & 0.69 & 0.78 & 0.88 & 0.97 & 1.08 & 1.18 \\
\hline W $200 \times 59.0$ & 0.44 & 0.50 & 0.56 & 0.63 & 0.70 & 0.79 & 0.89 & 0.99 & 1.10 & 1.22 & 1.35 & 1.48 & 1.63 & 1.75 & 1.89 & 2.04 \\
\hline W 200x71.0 & 0.74 & 0.82 & 0.92 & 1.03 & 1.14 & 1.26 & 1.38 & 1.52 & 1.66 & 1.81 & 1.95 & 2.08 & 2.24 & 2.40 & 2.54 & 2.69 \\
\hline W 200x86.0 & 1.17 & 1.29 & 1.42 & 1.56 & 1.70 & 1.85 & & 2.18 & 2.35 & & 2.67 & & 3.04 & 3.21 & 3.40 & 3.58 \\
\hline W 250x22.3 & 0.09 & 0.09 & 0.10 & 0.10 & 0.10 & 0.11 & 0.12 & 0.12 & 0.13 & 0.15 & 0.16 & 0.17 & 0.19 & 0.22 & 0.25 & 0.28 \\
\hline W $250 \times 25.3$ & 0.10 & 0.11 & 0.11 & 0.12 & 0.12 & 0.13 & 0.1 & 0.15 & 0.16 & 0.18 & 0.20 & 0.2 & 0.26 & 0.29 & 0.33 & 0.38 \\
\hline W 250x2 & 0.12 & 0.13 & 0.13 & 0.14 & 0.15 & 0.16 & 0.1 & 0.19 & 0.20 & 0.23 & 0.26 & 0.2 & .34 & .38 & 0.44 & 0.51 \\
\hline W 250x38.5 & 0.18 & 0.20 & 0.21 & 0.22 & 0.24 & 0.26 & 0.30 & 0.34 & 0.38 & 0.43 & 0.49 & 0.56 & 0.65 & 0.73 & 0.82 & 0.92 \\
\hline W 250x44.8 & 0.24 & 0.25 & 0.27 & 0.29 & 0.33 & 0.37 & 0.42 & 0.47 & 0.53 & 0.6 & 0.68 & & 88 & .97 & 1.08 & 1.20 \\
\hline W 250x89.0 & 0.97 & 1.08 & 1.21 & 1.34 & 1.48 & 1.63 & 1.7 & 1.95 & 2.12 & 2.3 & 2.46 & 2.6 & 2.84 & 3.04 & 3.21 & 3.41 \\
\hline W 250x101.0 & & & & & & & & & & & & & & & & 4.08 \\
\hline W 250x1 & 1.82 & 1.99 & 2.15 & 2.33 & 2.53 & 2.7 & 2. & 3.13 & 3.32 & 3. & 3.76 & & 20 & 4.42 & 4.66 & 4.77 \\
\hline W 310x23.8 & 0.10 & 0.10 & 0.10 & 0.11 & 0.11 & 0.1 & 0. & 0.13 & 0.14 & 0.1 & 0.16 & 0.1 & 0.2 & 0.22 & 0.24 & 0.27 \\
\hline W $310 \times 28.3$ & 0.12 & 0.12 & 0.13 & 0.13 & 0.14 & 0.15 & 0.16 & 0.17 & 0.18 & 0.20 & 0.22 & 0.2 & 0.28 & 0.32 & 0.36 & 0.42 \\
\hline W $310 \times 32.7$ & 0.14 & 0.15 & 0.15 & 0.16 & 0.17 & 0.18 & 0.2 & 0.21 & 0.24 & 0.2 & 0.30 & 0.3 & 0.39 & 0.44 & 0.51 & 0.58 \\
\hline W $310 \times 44.5$ & 0.21 & 0.23 & 0.24 & 0.26 & 0.28 & 0.30 & & 0.39 & 0.44 & 0.50 & 0.56 & 0.6 & 0.74 & 0.84 & 0.93 & 1.04 \\
\hline W $310 \times 5$ & 0.28 & 0.30 & 0.32 & 0.3 & 0.39 & 0.44 & 0.5 & 0.56 & 0.63 & 0.71 & 0.80 & & 1.0 & 1.14 & 1.26 & 1.39 \\
\hline W $360 \times 32.9$ & & & & & 0.16 & 0.17 & & 0.19 & 0.21 & 0.23 & & & 0.33 & 0.37 & 0.42 & 0.49 \\
\hline W $360 \times 39.0$ & 0.17 & 0.18 & 0.19 & 0.20 & 0.21 & 0.22 & 0.24 & 0.26 & 0.30 & 0.34 & 0.38 & 0.4 & 0.49 & 0.56 & 0.65 & 0.73 \\
\hline W $360 \times 51.0$ & 0.24 & 0.26 & 0.27 & 0.29 & 0.31 & 0.34 & 0.39 & 0.44 & 0.49 & 0.56 & 0.63 & 0.7 & 0.82 & 0.93 & 1.04 & 1.17 \\
\hline W $360 \times 57.8$ & 0.29 & 0.31 & 0.33 & 0.35 & 0.40 & 0.45 & 0.51 & 0.57 & 0.64 & 0.73 & 0.82 & 0.9 & 1.05 & 1.17 & 1.29 & 1.45 \\
\hline W $360 \times 64.0$ & 0.36 & 0.38 & 0.4 & 0.47 & 0.53 & 0.59 & 0.6 & 0.75 & 0.85 & 0.96 & 1.07 & 1.2 & 1.3 & 1.48 & 1.62 & 1.77 \\
\hline W $360 \times 72.0$ & 0.44 & 0.49 & 0.55 & 0.62 & 0.69 & 0.77 & 0.87 & 0.98 & 1.10 & 1.22 & 1.36 & 1.50 & 1.66 & 1.81 & 1.96 & 2.13 \\
\hline W 360x79.0 & 0.57 & 0.64 & 0.71 & 0.79 & 0.88 & 1.00 & 1.12 & 1.24 & 1.38 & 1.53 & 1.68 & 1.84 & 2.01 & 2.16 & 2.34 & 2.53 \\
\hline W 360x91.0 & 0.74 & 0.83 & & 1.03 & 1.16 & 1.30 & 1.44 & 1.59 & 1.75 & 1.92 & 2.11 & 2.30 & 2.46 & 2.66 & 2.86 & 3.06 \\
\hline W 360x101.0 & 0.99 & 1.09 & 1.22 & 1.36 & 1.51 & 1.67 & 1.83 & 2.01 & 2.19 & 2.39 & 2.59 & 2.75 & 2.97 & 3.19 & 3.40 & 3.61 \\
\hline W 360x1 10.0 & 1.22 & 1.36 & 1.51 & 1.67 & 1.84 & 2.00 & 2.19 & 2.39 & 2.60 & 2.81 & 2.97 & 3.18 & 3.43 & 3.66 & 3.87 & 4.12 \\
\hline W $360 \times 122.0$ & 1.55 & 1.71 & 1.87 & 2.05 & 2.23 & 2.43 & 2.65 & 2.87 & 3.09 & 3.27 & 3.51 & 3.76 & 4.03 & 4.26 & 4.53 & 4.81 \\
\hline
\end{tabular}

Table 7

Reinforcement ratio as function of the standard fire resistance requirement for development of the maximum negative bending moment, for composite beams with $10 \mathrm{~cm}$ slabs and Gerdau profiles series W410-W610

\begin{tabular}{|c|c|c|c|c|c|c|c|c|c|c|c|c|c|c|c|c|}
\hline \multicolumn{17}{|c|}{ Reinforcement ratio (\%) for standard fire resistance requirement (30 to 15 minutos), series W410-W610 - tc = $10 \mathrm{~cm}$} \\
\hline Name & 30 & 29 & 28 & 27 & 26 & 25 & 24 & 23 & 22 & 21 & 20 & 19 & 18 & 17 & 16 & 15 \\
\hline W 410x46.1 & & & 0.22 & 0.24 & & & & & & & & & & & & 0.88 \\
\hline W 410x60.0 & 30 & & & .36 & 39 & & & & & & & & & & & \\
\hline W $410 \times 6$ & & & & & & & & & & & & & & & & \\
\hline & & & & & & & & & & & & & & & & \\
\hline W 41 & & 0.64 & & 0.79 & & & & & & & & & & & & \\
\hline & & & & & & & & & & & & & & & & \\
\hline W 46 & ( & 0.3 & & 0.3 & & & & & & & & & & & & \\
\hline W 46 & & & & & & & & & & & & & & & & \\
\hline & & & & & & & & & & & & & & & & \\
\hline W 46 & & & & & & & & & & & & & & & & \\
\hline & & 0.6 & & 0.7 & & & & & & & & & & & & \\
\hline W 46 & & & & 0.9 & & & & & & & & & & & & \\
\hline W 460x & & & & & & & & & & & & & & & & .56 \\
\hline & & & & & & & & & & & & & & & & \\
\hline W 5 & & & & & & & & & & & & & & & & \\
\hline & & 0.4 & 0.5 & 0.5 & & & & & & & & & & & & \\
\hline & & & & & & & & & & & & & & & & \\
\hline W 530x & 0.6 & 0.6 & 0.77 & 0.8 & & & & & & & & & & & & 2.99 \\
\hline & & & & & & & & & & & & & & & & \\
\hline & & & 0.62 & & & & & 1.09 & 1.23 & & & & & & & 2.70 \\
\hline W 610x113.0 & 0.69 & & 0.85 & 0.94 & & & & & 1.64 & 1.83 & 2.02 & & & 2.74 & & 3.31 \\
\hline & & & & & & & & & & & & & & & & \\
\hline W 610x140.0 & 1.22 & 1.34 & 1.49 & 1.65 & 1.83 & 2.02 & 2.23 & 2.44 & 2.68 & 2.92 & & 3.42 & 3.75 & 4.08 & 4.40 & 4.77 \\
\hline W 610x174.0 & 1.89 & 2.09 & 2.30 & 2.54 & 2.79 & 3.03 & 3.31 & 3.61 & 3.92 & 4.19 & 4.53 & 4.90 & 5.33 & 5.72 & 6.16 & 6.62 \\
\hline
\end{tabular}


possible to adopt lower than the presented maximum reinforcement ratios by calculating the design negative bending moment resistance following the procedures described by Romagnoli and Silva [2]. Until more studies are developed, linear interpolation of the table results is not allowed. E.g.: another conclusion is that it will not be possible, by means of standard design procedures, to dispense fireproof coating for standard-fire resistant requirement greater than 19 minutes, regardless of the adopted reinforcement ratio.

The graph of Figure 5 shows the fire resistance time, that means, it illustrates the points at which the load factor is higher than 0.7, for Gerdau brand W200 steel profiles series by adopting the semicontinuous case. Figure 6 covers the results for other Gerdau branding profile series, hiding the curve markers for a better visualization. Note that the slab thickness ("tc") influence is very low, varying the resistance time generally in only one minute. It is also possible to notice that for lighter profiles the resistance time rarely reached more than 20 minutes and, in some cases, not even 15 minutes. This is clearly evident in the W310 series. For heavier and small height profiles, higher values were reached, approaching 30 minutes. This is

\section{Gerdau profile x Fire resistance time (semicontinuous case)}

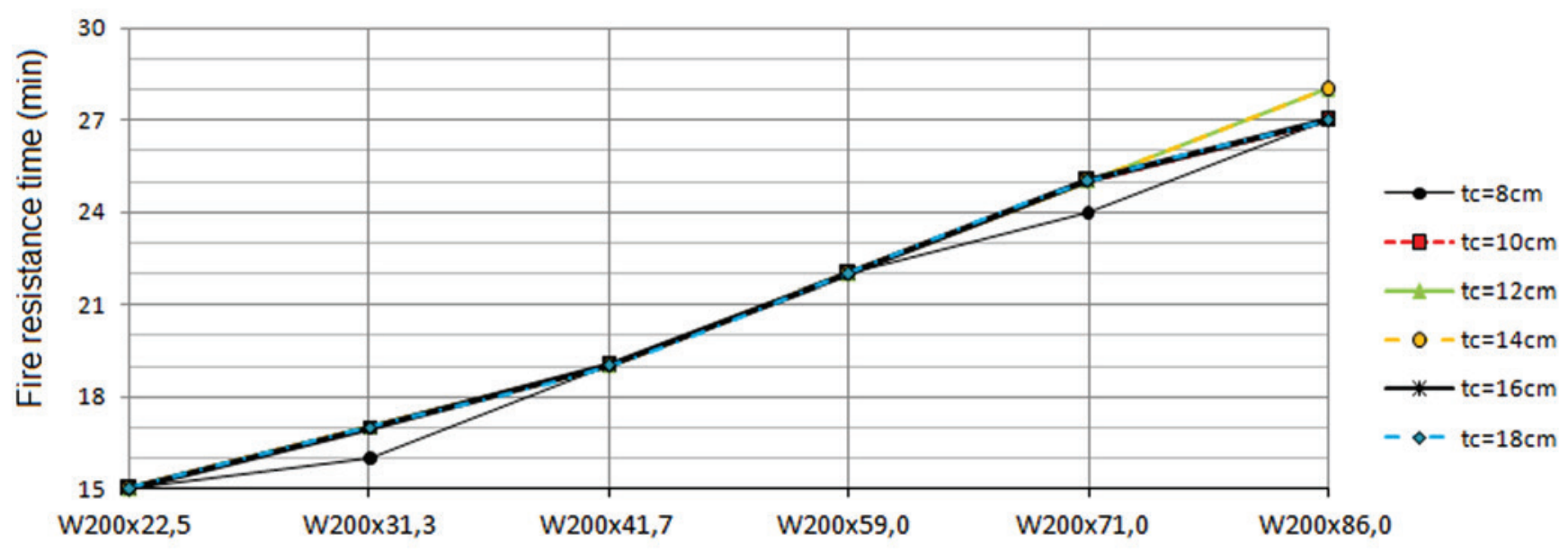

Analyzed Gerdau profile

\section{Figure 5}

Semi-continuous case fire resistance time (for 0.7 load factor) as function of the analyzed profile (Gerdau W200 series)

\section{Gerdau profile $x$ Fire resistance time (semicontinuous case)}

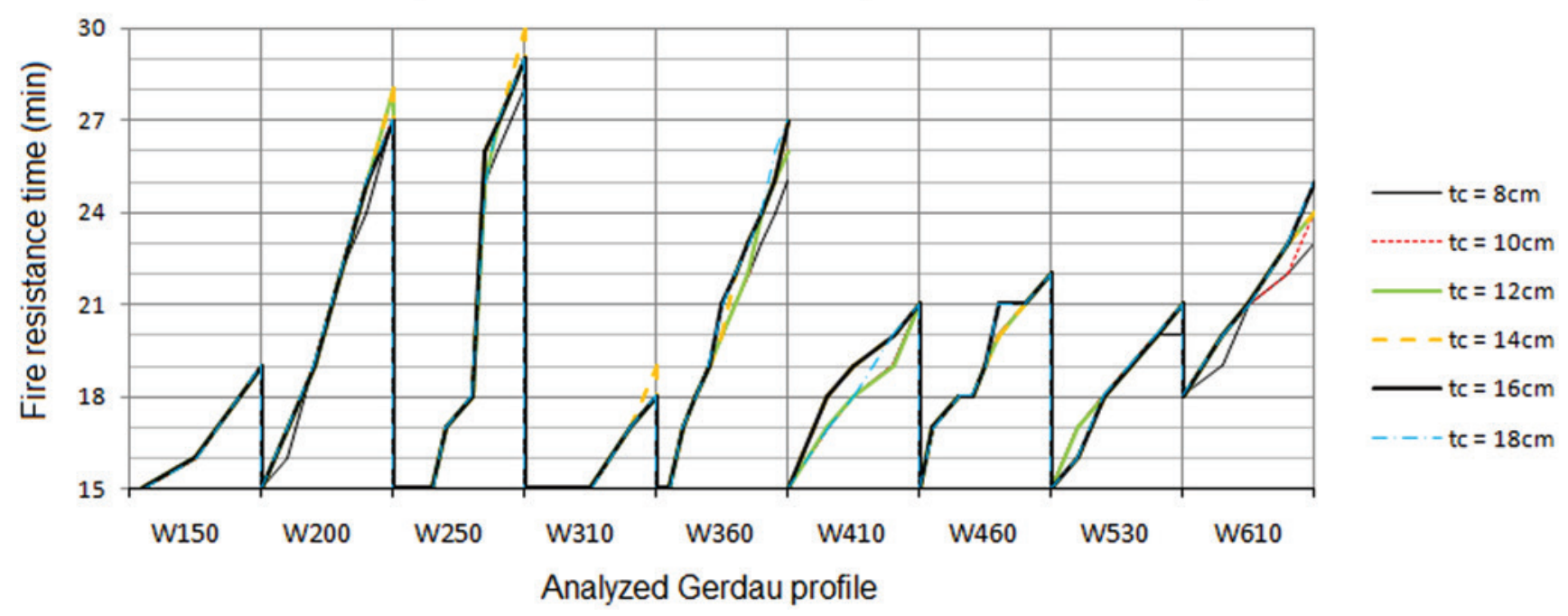

Figure 6

Semi-continuous case fire resistance time (for 0.7 load factor) as function of the analyzed profile 


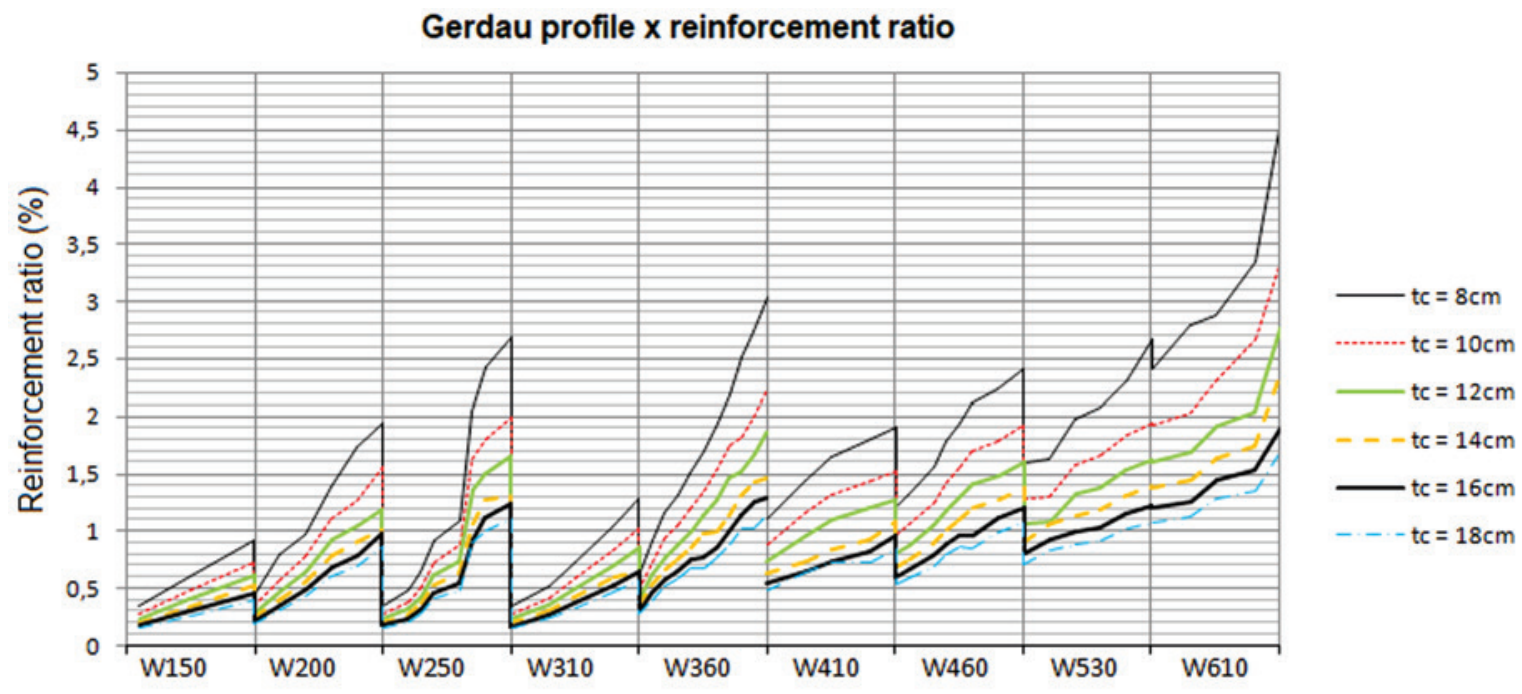

Analyzed Gerdau profile

\section{Figure 7}

Reinforcement ratio as function of the analyzed profile, for the semi-continuous case fire resistance time (for 0.7 load factor)

well noticed in the W200, W250 and W360 series. These profiles, however, are not commonly used as building floor beams, being more suitable for columns, where axial forces predominate.

The graph of Figure 7 indicates the reinforcement ratio for development of the maximum negative bending moment resistance for the fire resistance time shown in Figure 6, that means, the time in which the load factor was higher than 0.7 .

Lighter profiles have reasonable maximum reinforcement ratios, ranging from $0.5 \%$ to $1.5 \%$. Heavier profiles, however, require a very high reinforcement ratio, ranging from $2 \%$ to a maximum of $4.5 \%$.

\section{Conclusions}

The fire structural capacities of unprotected composite steel and concrete beams formed by Gerdau brand profiles and flat slabs were studied, considering the semi-continuity provided by the slab's reinforcement mesh and standard-fire resistance requirements between 15 and 30 minutes. Previous analyzes have shown that it is not possible to justify the absence of fireproof coating by following design standard procedures when considering standardfire resistance requirements of 30 minutes, minimum time allowed by the IT08 [12] tabular method. Lower times, although not as common, can be adopted according to the so-called equivalent time method, limited to 15 minutes.

The simplified analysis applies the design standard methods in which the formation of plastic hinges is evaluated in the supports and in the middle of the span. Simplifying hypotheses have been made in which indirect stresses, caused by thermal expansion, are neglected. An attempt to propose a method of intensifying the beam stresses without considering other complex phenomena such as geometric and materials non-linearity would excessively penalize the simplified model, leading to very conservative results (as already noted by Silva [14], in simply supported non-composite steel beams and frames subjected to high temperatures), going against the objective of evaluating the possibility of dispensing fireproof coating in some specific cases. This hypothesis was verified and validated with aid of numerical analyzes yet to be published. From the obtained results it can be concluded that:

- By design standard procedures it is possible to dispense fireproof coatings in composite beams when considering the semicontinuity in the support region for standard-fire resistance requirements of less than 30 minutes;

- Generally, lighter profiles, suitable to be used as buildings floor beams, obtained a load factor of 0.7 (simplified design criteria recommended by ABNT NBR 14323 [1] to evaluate the structural members internal forces in fire situation by comparison with the room's temperature design) for standard-fire resistance requirements ranging from 15 to 20 minutes;

- Heavier profiles obtained better results, with standard-fire resistance requirements between 20 and 30 minutes, but with a high reinforcement ratio, between $2 \%$ and $4.5 \%$, hardly put to practice. Complying with the initially proposed objective, it is possible to dispense fireproof coatings in specific cases, usually related to small buildings with a good fire risk management, resulting in standardfire resistance requirements close to 20 minutes according to the equivalent time method.

In case of profiles where the simplified analysis fails to demonstrate that fireproof coating can be dispensed, they can still be analyzed by numerical models. This work is under development by the authors.

\section{References}

[1] ASSOCIAÇÃO BRASILEIRA DE NORMAS TÉCNICAS. 
NBR 14323: Projeto de estruturas de aço e de estruturas mistas de aço e concreto de edifícios em situação de incêndio. Rio de Janeiro, 2013.

[2] ROMAGNOLI, L.C; SILVA, V. P. Sobre o aproveitamento da semicontinuidade para eliminar o revestimento contra fogo em vigas mistas de aço e concreto biapoiadas. Revista Ibracon de Estruturas e Materiais, 2017. No prelo.

[3] WANG, Y. C. Steel and composite structures. Behavior and design for fire safety. London: Spon Press, 2002.

[4] USMANI, A. S.; ROTTER, J. M.; LAMONT, S.; SANAD A. M.; GILLIE M. Fundamental principles of structural behavior under thermal effects. Fire Safety Journal, v.36, p. 721-744. Elsevier, 2001.

[5] KODUR V. K. R.; NASER M.; PAKALA P.; VARMA A. Modeling the response of composite beam-slab assemblies exposed to fire. Journal of Constructional Steel Research, v.80, p. 163-173. Elsevier, 2013.

[6] HUANG Z.; LIN S.; FAN M. The effects of protected beams and their connections on the fire resistance of composite buildings. Fire Safety Journal, v.78, p. 31-43. Elsevier, 2015.

[7] IOANNIDES S. A.; MEHTA S. Restrained versus unrestrained fire ratings for steel structures - a practical approach. Modern Steel Construction. Chicago: AISC, 1997.

[8] FAKURY R. H.; CASAS E. B.; PACÍFICO F. F.; ABREU L. M. P. Design of semi-continuous composite steel-concrete beams at the fire limit state. Journal of Constructional Steel Research, v.61, p.1094-1107. Elsevier, 2005.

[9] EUROPEAN COMMITTEE FOR STANDARDIZATION. EN 1994-1-2: Eurocode 4: Design of composite steel and concrete structures - part 1-2: General rules - Structural fire design. Brussels: CEN, 2005.

[10] FISCHER E. C.; VARMA A. H. Fire resilience of composite beams with simple connections: Parametric studies and design. Journal of Constructional Steel Research, v.128, p.119135. Elsevier, 2017.

[11] ASSOCIAÇÃO BRASILEIRA DE NORMAS TÉCNICAS. NBR 8800: Projeto de estruturas de aço e de estruturas mistas de aço e concreto de edifícios. Rio de Janeiro, 2008.

[12] CORPO DE BOMBEIROS - POLÍCIA MILITAR DO ESTADO DE SÃO PAULO. Instrução Técnica N08. Resistência ao fogo dos elementos de construção. São Paulo, 2011.

[13] ASSOCIAÇÃO BRASILEIRA DE NORMAS TÉCNICAS. NBR 15200: Projeto de estruturas de concreto em situação de incêndio. Rio de Janeiro, 2012.

[14] SILVA, V. P. Estruturas de aço em situação de incêndio. São Paulo: Zigurate Editora, 2001. 